Iryna Reshetnikova,

Dc. Sc., Professor, SHEE «Kyiv National Economic University named after V. Hetman», Ukraine

(iD) ORCID ID: 0000-0003-1445-4233

email: reshet2002@gmail.com

Henefa Shvydanenko,

Ph.D., Professor, SHEE «Kyiv National Economic University named after V. Hetman», Ukraine

iD ORCID ID: 0000-0001-6737-7935

email: henefa.shvydanenko@kneu.ua

Kateryna Boichenko,

Ph.D., Associate Professor, SHEE «Kyiv National Economic University named after V. Hetman», Ukraine

(iD) ORCID ID: 0000-0003-4636-067X

email: kateryna.boichenko@kneu.ua

Correspondence author: reshet2002@gmail.com

\title{
DETERMINANTS TO PROVIDE THE EFFICIENCY OF INTEGRATED DEVELOPMENT OF THE LIGHT INDUSTRY ENTERPRISES
}

\begin{abstract}
This article generalizes the arguments and counterarguments within the scientific discourse concerning the problems of integrated development of enterprises in the modern market economy. The main purpose of the research conducted is to create a methodological approach to the assessment and improvement of the integrated development efficiency of the Ukrainian light industry enterprises on the grounds of key determinants identification. For ensuring an extensive and systematic approach in this study, a three-step methodological base has been adopted. The interpretation and synthesis of high-quality data through sifting and sorting materials on key issues and subject matter of enterprise development in the context of integration have been conducted. The tendencies of development of the Ukrainian light industry enterprises have been analyzed to identify the key determinants. An assessment of their impact on the performance of integrated enterprise development has been made. The conducted research used the dialectical, structural and analytical as well as structural and functional analysis as a methodological tool. Methods for multicriteria analysis were used to determine the impact of the identified determinants, in particular, the calculation of the multivariate utility function and the normalization of determining factors. The article shows the results of the analysis of the light industry enterprises development with the help of such key determinants as providing of their own raw materials, availability of specialized mechanical engineering, repair base, properly qualified personnel, operating enterprises development. The integrated development of fifteen light industry enterprises has been diagnosed with the help of such main determinants as financial and resource support, intellectual and innovative potential, economic security, risk level, self-integration, the synergistic effect of integrated business processes. A group of enterprises has been identified, which the development level in the context of its integration is lower than estimated by the methods of classical performance diagnostics at the present stage. The group of enterprises has been identified, where integration processes are effective and have prospects for development. It is established that the integrated development implementation, due account being taken of the full complex of its determinants will promote greater usefulness and efficiency of the studied light industry enterprises functioning. The results of the conducted study can be useful for the efficiency improvement of domestic enterprises based on the integration
\end{abstract}

Keywords: efficiency, integrated development, utility, model, factor.

Introduction. The widespread adoption of integrating business technologies changes the design and management system completely, both in product sales processes and in the enterprise development in general. It creates the need for critical reflection and review of functioning business models in all light industry sectors. Meanwhile, the options choice and implementation rates of integrating business

Cite as: Reshetnikova, I., Shvydanenko, H., \& Boichenko, K. (2020). Determinants to Provide the Efficiency of Integrated Development of the Light Industry Enterprises. Marketing and Management of Innovations, 3, 157-169. http://doi.org/10.21272/mmi.2020.3-11 

Light Industry Enterprises.

technologies depend on the availability of real opportunities to adapt production to the changing requirements of providing competitiveness quickly and at the same time to master new disruptive technologies and deliver modern products to the market. In this connection, it is relevant to identify the determinants of integrated light industry development and to assess their impact on activity performance. They can become the basis for identifying the determinants of integrated enterprise development and measuring its level. Since the development integration nowadays acquires a new qualitative meaning and provides for influence both at the domestic or inter-firm and global level, there is an objective need to identify the factors that influence the companies' activities. Therefore, this study aims at generalizing the arguments and counterarguments within the scientific discourse on the integration of enterprise development in modern market conditions.

Literature Review. Integrative thinking is not new and is developing to solve urgent business problems (Downs, 2018). Nowadays, economic integration into the global information space is one of the determining factors for its competitiveness and efficient functioning. Under such aimed at knowledgeintensive production, integrated development and creation of the infrastructure for the intellectualization and information space formation of the enterprise (Asaul et al., 2019; Bacho et al., 2019), confirming the results of research conducted by modern scientists. Integrated enterprise development could be viewed from the perspective of sustainable development at both macro and micro levels (Bilan et al., 2019).

For example, Boudreau (2016) defines an integrated enterprise as a company that, following its management and activity strategy, purports to find a new aim: integrating production and shaping consumer value. Alac (2018) describes the application of a performance assessment system through three factors: decision making support, business integration and communication development. Meanwhile, the factor of activity conditions integration increase in efficiency of the business decision-making process.

A team of scientists (Mayer et al., 2019) relates the enterprise development integration to minimize the risk level of entrepreneurial activity. Ding (2018) and Wu (2019) proposed a Radio Frequency IDentification (RFID) designed to control in real-time and distribute the integrated production and transportation tasks between the enterprises. Handayani and Nirwan (2019), based on the logistics companies research, concluded that the enterprises should pay more attention to an integrated environment and mutual understanding of consumer value. According to Al Hadidi and Baghdadi (2019), traditionally, interaction is implemented based on the specific nature of the activity, resulting in costly integration architecture, as it does not take into consideration the semantic aspect of interactions. Meanwhile, for enterprises interaction, in particular Extended Enterprise (EE) and Virtual Enterprise (VE), development integration is to some extent a collaboration between poorly connected enterprises, gathering their economic resources for goods (services) production.

A team of scientists (Chavarría-Barrientos et al., 2018; Prause and Hoffmann, 2020) believes that next-generation manufacturing companies need to be perceptive, smart and sustainable to be competitive. In this aspect, "receptivity» means awareness of the context at the internal and external levels; "smart» refers to knowledge-based companies which adapt to changes, and «sustainability» refers to the ability to act without damaging the environment, society and/or economy (Vasylieva et al., 2018). Some researchers (Ershova et al., 2018; Zhang et al., 2018) have developed an integrated model of stimulating innovation enterprise activity, based on mechanisms to strengthen its structural components: intelligence, innovations and innovativeness. Petrenko and Melnykova (2018), Pietruszka-Ortyl (2019) distinguish the integration processes management based on the management system adaptability to changes of the external factors and provision of the search for new organizational, structural and functional forms, approaches to their management organization. The principle of integrated relations voluntariness in the general policy system must be harmonized with the principle of internal monodirectional and partial interests of the integration process subjects at the level of individual companies and the state as a whole (Lyulyov et al., 2017). The conducted research also considers the life cycle of integrated enterprise 

Light Industry Enterprises.

development within three zones of key fluctuations indicators: synchronicity, plesiochronous, disintegration (Boichenko et al., 2019).

Modern publications (Badiru et al., 2018) highlighted an integrated system approach to manufacturing and entrepreneurship, including the design process, system modelling, commercial entrepreneurship, anticipation, inventory management, product design and project management. Many scholars link the enterprise development integration with the information systems (Bork et al., 2018), the information system formation and analytical support of economic activity (Ashkezari et al., 2018). They also believe that one of the most important elements of modern integrated transformations is information systems and technologies. But they should be capable of forming large amounts of information and knowledge, transmitting them over a distance, accumulating, storing and shaping new intellectual products in the company development process (Ma and Wang, 2016; Moisescu and Sacala, 2016). The team of scientists (Alzoubi et al., 2018) emphasizes effective and strong interrelations between stakeholders engaged in the process of integrated development. Consequently, they have developed and justified a quantitative assessment model for analyzing flexible corporate architecture for geographically remote stakeholders.

Several scholars are considering stable enterprise development based on resource integration (Chofreh et al., 2018), and also formulating a reference model for integrating of B2B business processes (Jung et al., 2016).

Thus, the multidimensionality of the «integrated development» concept allows to define it:

- $\quad$ first of all, as the formation of a resource management business model;

- secondly, as a system of social and economic as well as organizational and technical relations based on the use and introduction of information and telecommunication technologies;

- thirdly, as an implementation of integrated technologies, aimed at forming the required conditions for harmonizing the interests of all business stakeholders.

Nowadays, the factors, parameters and directions of improving the enterprise development efficiency are vigorously investigated. Despite the numerous factors influence on the company development effectiveness level, many aspects of this course of investigation remain insufficiently covered. It relates to the problematic of meaningful content and the concretization of the performance improvement determinants based on the integrated development of business potential, due account being taken of intellectual and innovative content. For filling these science gaps, the need to identify the determinants of integrated enterprise development, to break through competitiveness increase, serves as the key motivation for conducting the research. It has enabled the determination of this article's purpose - to form a methodological approach to assessment and increase in the efficiency of integrated development of the Ukrainian light industry enterprises based on its key determinants identification.

Methodology and research methods. The research is based on scientific approaches to improve performance according to integrated development in two directions: identifying and removing barriers to the implementation of an integrated business model, as well as examining and harmonizing the positions of different stakeholder groups in the integration processes. This study has purposeful nature, which enables us to compare key concepts related to the development of light industrial enterprises with the primary sources of actual data. For providing an extended and systematic approach, a three-step methodological framework was adopted in this research. At the initial investigation stage, for generalizing the actual data and identify gaps in existing research the interpretation and high-quality data synthesis were carried out by sifting and sorting materials on key issues and themes of enterprise development in the context of integration. At the second phase, data were collected on trends in the development of national light industry enterprises with a purpose of identifying the key determinants of ensuring its efficiency increase based on integration. In the third stage, electronic and printed copies of documents and publications were analyzed to reflect and assess the impact of the definite determinants on the productivity level of the light industry enterprises integrated development. 

Light Industry Enterprises.

The authors selected 15 light industry enterprises for the research conducted, which are representatives of its different sub-sectors. Diagnostics of development was carried out for each of them on such determinants as financial and resource support, intellectual and innovative potential, economic security, risks level, self-integration, the synergetic effect of business processes integration. The determinants of the companies' development were marked by the symbol $\mathrm{D}$, and the total number of factors that contribute to this development $n$, then $D=\{d 1, d 2, \ldots, d n\}$. For determining the impact of these determinants, it is advisable to use the following methods of multicriteria analysis, such as the calculation of the multivariate utility function and the particular factors normalization.

According to the decision-making theory, it is necessary to choose integrity, taking into account the maximization of the expected consumer value. For determination of this process parameters, we will introduce the concept of the integrated process utility. This indicator reflects the prevalence degree of one integrated process over another, taking into consideration the integrated development goals. Thus, the utility function is a function of ordering a determinant set according to their prevalence in the business development process. The utility function UF (d) can be defined in different ways. However, it is suggested to use an additive model to solve the problems of this research. Meanwhile, the utility function will include the total amount of normalized values for achievement of the enterprise development aims, as well as the impact of risks and threatening events. Data normalization lies in bringing development indicators to a single measurement scale. For normalizating the use of linear transformation is proposed according to the formula (1):

$$
d_{i}^{\text {norm }}= \begin{cases}\frac{d_{i}-d_{i}^{\text {min }}}{d_{i}^{\text {max }}-d_{i}^{\text {min }}}, & d_{i} \rightarrow \max \\ \frac{d_{i}-d_{i}^{\text {max }}}{d_{i}^{\text {min }}-d_{i}^{\text {max }}}, & d_{i} \rightarrow \text { min }\end{cases}
$$

where $\mathrm{d} i$ is the ith discriminant of development; $\mathrm{i}=\{1,2,3,4,5,6\} ; d_{i}^{\text {min }}$ is the minimum value of the ith discriminant; $d_{i}^{\text {max }}$ is the maximum value of the ith discriminant; $d_{i}^{\text {norm }}$ is the normalized value of the ith discriminant.

It should also be noted that discriminants $\mathrm{d} 1$ - $\mathrm{d} 5, \mathrm{~d} 7$, d8 need maximization, and $\mathrm{d} 6$ needs minimization because it is related to the level of risk. The process of discriminants normalization of enterprise development allows to bring them to a single measurement scale: $d_{i}^{\text {norm }} \in[0 ; 1]$. Zero characterizes the minimum value of the discriminant $\left(d_{i}^{\text {min }}\right)$ and one, respectively, the maximum of the discriminant $\left(d_{i}^{\text {max }}\right)$. Intermediate values lying on the interval $(0 ; 1)$ reflect the degree of approximation to the maximum of the discriminant value. Thus, the utility function in the development process can be determined by the formula (2):

$$
U F_{d}(d)=\sum_{i=1}^{6} k_{i} * d_{i}^{n o r m}
$$

where $d$ is the discriminant of enterprise development, di $\in \mathrm{D}$; $k i$ is the coefficient of discriminant $d$ advantage, which can be determined, for example, by the method of calculating pairwise matrices.

In this case $k i \leq 1, \sum_{i=1}^{6} k_{i}=1$. If all discriminants advantages are equal or in the absence of preference data, $k i$ will have the same value for all discriminants. It can be calculated with the help of the formula (3): 
I., Reshetnikova, H., Shvydanenko, K., Boichenko. Determinants to Provide the Efficiency of Integrated Development of the Light Industry Enterprises.

$$
k=\frac{1}{i}
$$

Six discriminants $(k=1 / 6)$ were selected to determine the development function utility (UFd $(d))$, and for the integrated development utility function at the moment of research (UFbid (d) - before integrated development). Also considering the proposed measures for integrated development (UFaid (d) - after integrated development), two more discriminants (self-integration, the synergistic effect of integrated business processes) were added, that is why $k=1 / 8$. The collected data are organized and grouped following the course of the study. Descriptive statistics were used to analyze the data. The following methods were employed during the process of isolation and assessment of the influence of the definite determinants on the performance of integrated development of light industry enterprises:

- dialectical method in the process of analyzing and generalizing particular aspects of scientific knowledge, which examine the scientific views evolution on the essence of integrated enterprise development, as well as the interrelations of structural elements of the integrated business model considering the needs of business stakeholders;

- $\quad$ structural and functional analysis of the principles of economic phenomena systematic study and processes for the identification and implementation of the components of integrated development of light industry enterprises, taking into consideration certain determinants, particularly, own raw material base, special machine engineering, repair base, qualified personnel availability, scientific and educational base, operation of the businesses and transport accessibility;

- $\quad$ system and analytical method, according to which the study of determinants of integrated development of light industry enterprises is considered as a development factor of the country's economy as a whole and increase its competitiveness in the global market.

Results. The integrity of development can be considered as a multifaceted phenomenon, simultaneously acting:

- firstly, as a method of achieving the purpose and set the goals of business development;

- secondly, as a procedure for considering and solving problems in the process of the company's activity;

- thirdly, as the technology of creation, functioning and changes of the enterprise;

- fourthly, as a system of management measures to achieve the strategic intentions of the economic entity.

Integrated development is a unification of resources and business potential aimed at ensuring the long-term effectiveness of an enterprise to transform it into a practice of coordinated actions and management technologies. A complex model of integrated enterprise development is proposed based on definite characteristics (Fig. 1). Based on the formed model, an attempt was made to provide the author's interpretation of integrated enterprise development. Integrated enterprise development is a complex of interaction means of internal and external determinants, ensuring optimal coordination, synchronization and coherence of the business processes network taking into consideration intellectual and innovative content of managerial influences.

In case of significant demand for light industry products, there is an obvious need to integrate this industry through the formation of appropriate business processes. It is advisable to combine economic relations of light industry enterprises with the subsequent inclusion of enterprises of other economic entities in the chain.

The formation of the merger may use the traditional approach. Its structure will be formed by the garment, knitwear and leather sub-industries, chemical industry enterprises, which produce chemical fibres. Integrated development processes should also include educational institutions providing staff 
I., Reshetnikova, H., Shvydanenko, K., Boichenko. Determinants to Provide the Efficiency of Integrated Development of the Light Industry Enterprises.

training for light industry enterprises, research and scientific organizations and infrastructure organizations.

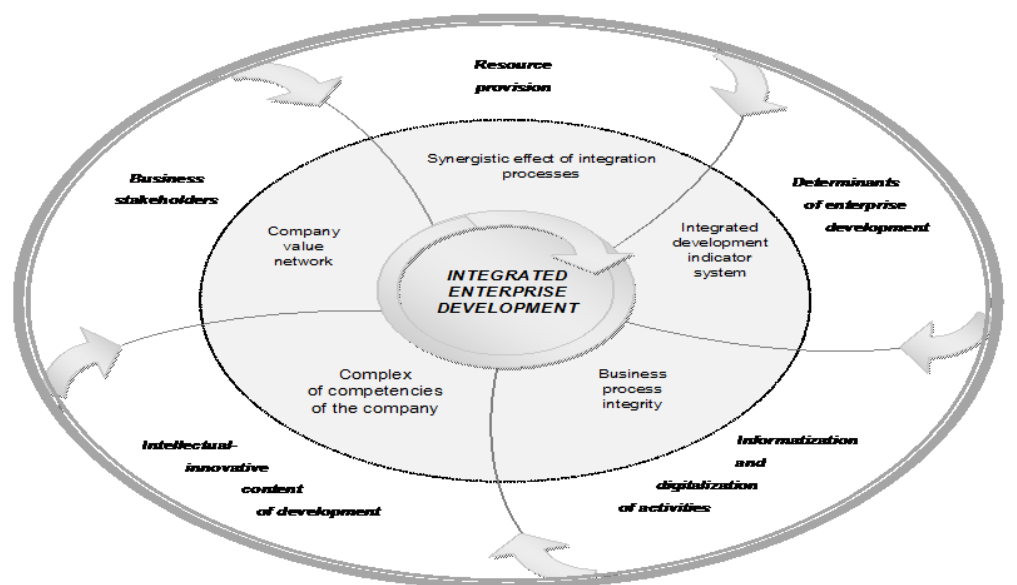

Figure. 1. Model of integrated enterprise development

Source: developed by the authors.

Manufacture of textile, clothing, leather, leather goods and other products constitute the largest share of light industry sales. The share of light industry in Ukrainian commodity imports is $2.4 \%$ and in exports $5.1 \%$ (Table 1). In general, this indicates a low-efficiency level of foreign economic activity.

Table 1. Foreign trade of Ukraine in light industry commodity groups in 2019

\begin{tabular}{|l|l|c|c|c|c|c|c|}
\hline \multirow{2}{*}{ № } & \multicolumn{1}{|c|}{$\begin{array}{c}\text { Name of product } \\
\text { group }\end{array}$} & $\begin{array}{c}\text { value, } \\
\text { thousand } \\
\text { US\$ }\end{array}$ & $\begin{array}{c}\text { rate, \% } \\
\mathbf{2 0 1 9 /} \\
\mathbf{2 0 1 8}\end{array}$ & $\begin{array}{c}\text { share, } \\
\mathbf{\%}\end{array}$ & $\begin{array}{c}\text { value, } \\
\text { thousand } \\
\text { US\$ }\end{array}$ & $\begin{array}{c}\text { rate, \% } \\
\mathbf{2 0 1 9 /} \\
\mathbf{2 0 1 8}\end{array}$ & $\begin{array}{c}\text { share, } \\
\%\end{array}$ \\
\hline 1 & Pelts & 82661.2 & 93.1 & 6.9 & 153157 & 88.2 & 5.0 \\
\hline 2 & Leather goods & 46887.3 & 93.1 & 3.9 & 121424 & 114.5 & 3.9 \\
\hline 3 & Fur; fur products & 19531.7 & 74.5 & 1.6 & 8441.9 & 158.5 & 0.3 \\
\hline 4 & Silk & 19531.7 & 74.5 & 1.6 & 8441.9 & 158.5 & 0.3 \\
\hline 5 & Wool & 5204.3 & 68 & 0.4 & 46765.6 & 87.8 & 1.5 \\
\hline 6 & Cotton & 2517.4 & 93.1 & 0.2 & 145057 & 92.5 & 4.7 \\
\hline 7 & $\begin{array}{l}\text { Other plant textile } \\
\text { fibers }\end{array}$ & 910.6 & 68.8 & 0.1 & 12663.5 & 124 & 0.4 \\
\hline 8 & $\begin{array}{l}\text { Synthetic or artificial } \\
\text { threads }\end{array}$ & 12522.4 & 121.3 & 1.0 & 234310 & 83.7 & 7.6 \\
\hline 9 & $\begin{array}{l}\text { Synthetic or artificial } \\
\text { staple fibres }\end{array}$ & 21774 & 104.4 & 1.8 & 208572 & 92.3 & 6.7 \\
\hline 10 & $\begin{array}{l}\text { Wadding, felt; twine, } \\
\text { bindings, cables and } \\
\text { ropes and articles } \\
\text { thereof: }\end{array}$ & 97315.2 & 116.5 & 8.1 & 141214 & 96.3 & 4.6 \\
\hline 11 & $\begin{array}{l}\text { Carpets and other } \\
\text { textile floor coverings }\end{array}$ & 37784.5 & 96.525 & 3.1 & 417174.1 & 121.55 & 13.5 \\
\hline
\end{tabular}


I., Reshetnikova, H., Shvydanenko, K., Boichenko. Determinants to Provide the Efficiency of Integrated Development of the Light Industry Enterprises.

\begin{tabular}{|c|c|c|c|c|c|c|c|}
\hline \multicolumn{8}{|c|}{ Continued Table 1} \\
\hline 12 & $\begin{array}{l}\text { Special fabrics; lace; } \\
\text { gobelins; embroidery }\end{array}$ & 123988 & 91 & 10.3 & 398458 & 152.9 & 12.9 \\
\hline 13 & Textile clothes & 391699 & 96.9 & 32.5 & 370227 & 152.9 & 12.0 \\
\hline 14 & $\begin{array}{l}\text { Other ready-made } \\
\text { textile articles }\end{array}$ & 153411 & 108.1 & 12.7 & 353147 & 130.7 & 11.4 \\
\hline 15 & $\begin{array}{ll}\text { Shoes, } & \text { hats, } \\
\text { umbrellas } & \end{array}$ & 188380 & 90.5 & 15.6 & 473390 & 129.7 & 15.3 \\
\hline 16 & Total: & 1204118.7 & 92.7 & 100 & 3092443.8 & 118.9 & 100 \\
\hline
\end{tabular}

Source: State Statistics Service of Ukraine (2020).

Following the priorities of providing the population with light industry goods, it is advisable to highlight several levels of integrated light industry development based on such its key determinants: own modern raw materials base; specialized mechanical engineering that produces workbenches, machines, equipment, tools at the international standards level; repair base; qualified personnel availability; dynamic development of operating enterprises. The greatest development of the light industry can be achieved in those countries or regions where all the above factors appear, namely, all components of the formation chain. First of all, consumer value in the local territory is created and can be consolidated into an integrated business structure or used in the integrated business model. In practice, it is rarely achieved both within the single region and in the territory of a particular country. A deeper division of labour results, on the one hand, in narrowing the specialization of enterprises located in one area in the production of a single item, and, on the other, in need to integrate enterprises located in different areas to create a unified light industry product. Let us consider in depth the presence of these determinants in the domestic light industry.

1. Own raw materials base. Nowadays, only a part of the domestic sub-sectors of light industry in Ukraine are provided with domestic raw materials:

- linen industry: Ukraine is currently unable to provide not only the external but also the internal market with raw materials for the production of the required volumes of flax-fibre products. The flax seed harvest in 2018-2019 marketing year has shrunk to 23,000 tonnes and became the lowest one in the last 10 years. It is anticipated that flax seed export in 2018-2019 marketing year will be $47 \%$ lower than in the previous marketing year, the minimum volume in the last 5 years. The flax cropland has fallen to 17,700 hectares in 2019, which became the minimum figure for the last 15 years. Flax harvest is forecasted to reach the rate of 18,000 tonnes in 2019 , and in such a case it will be the lowest one in the last 12 years. Internal flax consumption in 2019-2020 marketing years is anticipated at the level of 8,000 tons (which is $13 \%$ less than in the previous period). Export potential for flax in 2019-2020 marketing years is estimated at 10,000 tons (which is $17 \%$ less than in the last period) (APK-Inform, 2019). The specificity of Ukrainian flax (fibre flax) is the large amount output of low-quality fibrous raw materials (2/3 of the total production volume), which can be used the only Solution to this situation may be the development and introduction of new technologies for the modification of mixed fibres for textile materials: cotton and linen, linen and wool, linen and synthetic yarn;

- wool production: nowadays, domestic wool production can only partially meet the needs of the textile industry;

- cotton and silk production is completely dependent on supplies of imported raw materials;

- leather and shoe industry: the main raw material is genuine leather, which depends on the species and animal breed. Not all animals breeds are grown, and the required amount of leathers for the respective species is not provided. Almost 150 shoe companies operate in domestic regions. Most of these items are produced in the Zhytomyr region $-29.7 \%$ of the total domestic production. Meanwhile, the sold shoes volume in the country exceeds its production volume more than twice as a result of cheap footwear import 

Light Industry Enterprises.

from China and Turkey. Leading shoe enterprises to operate in the cities of Baranivka, BelgorodDnestrovsky, Berdychiv, Dnipro, Zaporizhya, Zhytomyr, Kropyvnytskyi, Chernihiv and others. It should also be noted that due to the introduction of a free-trade regime with the EU, the Chernihiv shoe factory «Bereginya», with the assistance of an Austrian company, sells its products in the EU member states under the trademark «Primissimi» (Aleksandrova, 2015);

- fur industry: the main raw material is natural fur, which varies in animal species of. Traditionally, the fur raw materials supply in Ukraine is carried out through the operations of animal husbandry organizations and as a result of hunting. Modern directions of replenishment with fur raw materials of Ukrainian fur processing enterprises are characterized by procurement through auctions. The largest fur suppliers are Europe $(60 \%)$, China (25\%), North America (10\%) and other countries $(5 \%)$ (Hryshchenko et al., 2015);

- production of nonwoven materials, synthetic fibres, fabrics: produced from hydrocarbon raw materials, depends on the quality of raw materials and processing technology. Approximately $18 \%$ of all textile production in Ukraine is made of natural, artificial and synthetic silk fabrics. One of the largest Ukrainian enterprises of light industry is Cherkasy Textile Mill, which specializes in the production of artificial and synthetic silk, and Kyiv Silk Mill specializes in natural silk production (Boiko and Tarasova, 2019).

2. Special mechanical engineering, producing workbenches, machines, equipment, tools. Nowadays, Ukrainian machinery does not produce modern equipment for the light industry employing advanced technologies. Domestic enterprises import equipment from other countries: Italy, China, Germany, Turkey, Japan.

3. Repair base. As a rule, only certified manufacturer centres can carry out warranty and further repairs of used imported equipment.

4. The qualified personnel availability. In the early 1990s, the number of employees in the industry was 750,000 , which is almost 9 times more than in 2018. The main reason for the employees' outflow to the other economic sectors is the relatively low salary level. Research conducted by scientists demonstrated that the cost of wages composes $10-20 \%$ of the production cost. However, over recent years the employees' number in this field has started to increase (Boiko and Tarasova, 2019).

5. Functioning enterprises. The domestic market for light industry products is sufficiently competitive, with more than 2,300 enterprises operating on it, with an average of 85,000 personnel, and their output reaching 22 billion UAH. The market is represented by small (86\% of the total) and medium (14\%) enterprises. The level concentration of domestic enterprises in the market is not high. Thus, 327 mediumsized enterprises sell $79.4 \%$ of products for 17.7 billion UAH, respectively, in 2014 , small enterprises sell $20.6 \%$ of products for 4.6 billion UAH. Light industry enterprises generally operate at a profitability level of 4-10\% (Deineko et al., 2018).

Domestic light industry enterprises need to employ an integrated business model that creates new functionalities that meet all stakeholders ' needs at a minimal cost. Diagnostics of development was carried out for each of them on such determinants as financial and resource support, intellectual and innovative potential, economic security, risks level, self-integration, the synergetic effect of business processes integration. The calculation of the utility function UF (d) lies in the interval [0; 1] (Table 2). The closer UF (d) to one is, the more economically justified is the implementation of integrated enterprise development. Perspectively, it will be advisable to rank several integrated processes, depending on the growth of the utility function to form the most effective integrated complex.

It should also be noted that the function mentioned above of utility is considered within the ordinal approach to the utility theory. The obtained values of the utility function create the possibility to compare them with each other; thus, only the rejection sign is important, that is, if UFd (d)> UFaid (d), the efficiency of integrated development is higher (Fig. 2). 
I., Reshetnikova, H., Shvydanenko, K., Boichenko. Determinants to Provide the Efficiency of Integrated Development of the Light Industry Enterprises.

Table 2. Values normalization for discriminants of light industry enterprises

\begin{tabular}{|c|c|c|c|c|c|c|c|c|c|c|c|}
\hline $\begin{array}{l}\text { Name of the } \\
\text { enterprise }\end{array}$ & d1 & $\mathrm{d} 2$ & d3 & d4 & d5 & d6 & d7 & d8 & UFd(d) & $\begin{array}{l}\text { UFbid( } \\
\text { d) }\end{array}$ & $\begin{array}{l}\text { UFaid( } \\
\text { d) }\end{array}$ \\
\hline $\begin{array}{c}\text { PJSC } \\
\text { «Arsania» }\end{array}$ & 0.000 & 0.103 & 0.183 & 0.186 & 0.060 & 0.567 & 0.628 & 0.834 & 0.205 & 0.278 & 0.339 \\
\hline PJSC «Lesia» & 0.215 & 0 & 0.202 & 0.198 & 0.287 & 0.259 & 0.432 & 0.742 & 0.203 & 0.385 & 0.431 \\
\hline PJSC «Gloria» & 0.415 & 0.256 & 0.000 & 0.720 & 0.252 & 0.000 & 0.408 & 0.765 & 0.274 & 0.283 & 0.585 \\
\hline $\begin{array}{c}\text { PJSC } \\
\text { «Volodarka» }\end{array}$ & 0.262 & 0.000 & 0.432 & 0.391 & 0.266 & 0.098 & 0.451 & 0.723 & 0.249 & 0.333 & 0.544 \\
\hline PJSC «Goryn» & 0.293 & 0.735 & 1.000 & 0.104 & 0.157 & 0.184 & 0.743 & 0.532 & 0.363 & 0.411 & 0.509 \\
\hline $\begin{array}{c}\text { PJSC } \\
\text { «Edelwicka» }\end{array}$ & 0.213 & 0.435 & 0.525 & 0.129 & 0 & 0.584 & 0.673 & 0.438 & 0.448 & 0.383 & 0.465 \\
\hline PJSC «Kalyna» & 0.076 & 1.000 & 0.000 & 0.544 & 0.286 & 0.652 & 0.408 & 0.811 & 0.426 & 0.360 & 0.478 \\
\hline $\begin{array}{c}\text { PJSC «Rivne } \\
\text { nonwovens } \\
\text { factory» }\end{array}$ & 0.158 & 0.521 & 0 & 0.201 & 0.382 & 0.082 & 0.365 & 0.723 & 0.229 & 0.335 & 0.517 \\
\hline $\begin{array}{l}\text { PJSC «Santa } \\
\text { Ukraine» }\end{array}$ & 0.303 & 1.000 & 0.224 & 0.124 & 0.697 & 0.189 & 0.561 & 0.845 & 0.365 & 0.339 & 0.528 \\
\hline $\begin{array}{l}\text { PJSC «Textile } \\
\text { factory «Rose» }\end{array}$ & 0.499 & 0.205 & 0.244 & 0 & 0.662 & 0.516 & 0.485 & 0.594 & 0.450 & 0.416 & 0.535 \\
\hline $\begin{array}{c}\text { PJSC } \\
\text { «Khmelnytsky } \\
\text { garment factory } \\
\text { «Lileya» } \\
\end{array}$ & 0.192 & 0.430 & 0.620 & 0 & 0.454 & 0 & 0.347 & 0.876 & 0.283 & 0.246 & 0.541 \\
\hline $\begin{array}{c}\text { PJSC } \\
\text { «Cherkassy } \\
\text { textile mill» }\end{array}$ & 0.152 & 0.158 & 1 & 0.664 & 0.315 & 0.568 & 0.864 & 0.388 & 0.412 & 0.403 & 0.429 \\
\hline $\begin{array}{c}\text { PJSC } \\
\text { «Chernihiv } \\
\text { Shoe factory } \\
\text { «Bereginya» }\end{array}$ & 0.274 & 0.588 & 0.387 & 0 & 0.215 & 0 & 0.425 & 0.673 & 0.244 & 0.252 & 0.601 \\
\hline $\begin{array}{c}\text { PJSC } \\
\text { «Garment } \\
\text { factory } \\
\text { «Voronin» }\end{array}$ & 0.347 & 0.655 & 0.397 & 0.781 & 0.894 & 0.278 & 0.521 & 0.642 & 0.460 & 0.544 & 0.590 \\
\hline $\begin{array}{c}\text { PJSC } \\
\text { «Garment } \\
\text { factory } \\
\text { «Zoryanka" }\end{array}$ & 0.405 & 0.599 & 0.359 & 0.614 & 0.192 & 0 & 0.743 & 0.586 & 0.249 & 0.396 & 0.714 \\
\hline
\end{tabular}

Source: developed by the authors based on the materials of enterprises.

The utility assessment of the current development level of the investigated enterprises and considering the discriminants of integrated development demonstrates that by now, the development level of PJSC «Edelwick», PJSC «Kalyna», PJSC «Santa Ukraine», PJSC «Khmelnytsky garment factory «Lileya», PJSC «Cherkasy textile mill» in the context of their integration is lower than can be considered based on the usual determinants set. 


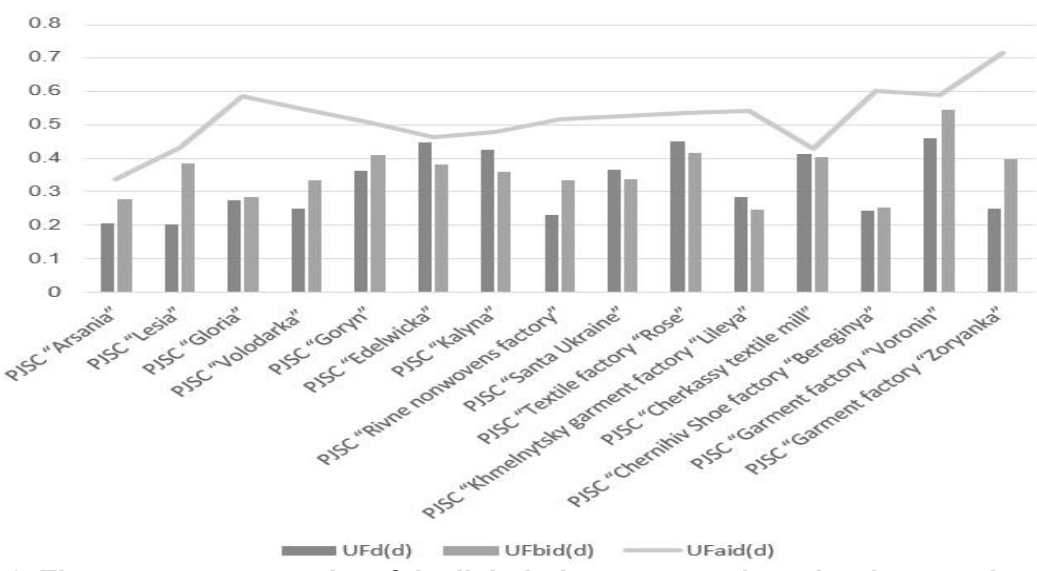

Figure. 2. The assessment results of the light industry enterprises development by a utility function, taking into consideration its integration possibilities

Source: developed by authors based on enterprise materials.

In other companies, the processes of integration are functioning successfully and have a development perspective. Remarkably, the highest result was achieved by PJSC «Production and commercial firm «Lesia». The introduction of an integrated development model for these companies, due account being taken of its full determinants range, will promote the utility and their operational effectiveness.

Conclusions. Enterprise development integration can be considered as the formation of a business model of rational resources use. Moreover, it can be regarded as the implementation of integrated breakthrough technologies in the process of value chain formation and modern innovative and intellectual system, aimed at the formation of required conditions for all business stakeholders' interests harmonizing.

The formation and justification of promising development directions require respecting several existing features specific to the domestic light industry, namely:

- a focus on production concentration is formed. Consequently, support of the large enterprises' development results in unreasonably high costs items production. Particularly in the case of textile, garment and leather sub-industries, which in the conditions of existing problems with the sale of products and incomplete production operations complex to create items with the high value-added cost;

- use of mostly outdated technologies and equipment by operating enterprises of the garment and textile industry, which does not allow to produce competitive goods;

- the complex and lasting adaptation of large companies to the dynamically changing demand for manufactured products in a turbulent market environment, resulting in products not always meeting the client-orientation criteria, enabling the loss of particular market segments;

- mostly unjustified the high dependence level of light industry on the high-quality import, mainly foreign raw materials, first of all, for the garment and leather industries needs;

- relatively low-quality level of personnel potential of light industry enterprises.

Fifteen light industry enterprises have been identified for the determinants of integrated development to assess the effectiveness of integrated development. They include financial and resource support, intellectual and innovation potential, economic security, risk level, self-integration, the synergistic effect of integrated business processes. Multicriterial analysis methods, particularly, multivariate utility function and normalization of diagnostic results, were used to identify the impact of these determinants. A group of enterprises has been identified, for which, nowadays, the development level in the context of its integration is lower than it can be considered based on classical diagnostics of their activity performance. It also 

Light Industry Enterprises.

highlights companies, which integration processes are successful and focused on perspective effective development. It is established that the implementation of integrated development, considering the full complex of its determinants will help to increase the utility and performance of functioning of the studied light industry enterprises. A method for assessing integrated development was proposed, including the calculation of an eight-criterion utility function and discriminants that reflect activity performance, as well as the level of exposure to risk factors. In perspective, the developed model can be expanded, considering the specificity of the industry of the studied enterprises and the possibilities of entering the international market. This method of assessing the effectiveness of integrated development has open-ended nature, allows complementing and changing the composition of the employed determinants, considering strategic changes and the objective need to harmonize the interests of all stakeholders in the investigated business.

Author Contributions: conceptualization, I. R., H. S. and K. B.; methodology, I. R., H. S. and K. B.; validation, I. R., H. S. and K. B.; formal analysis, H. S.; investigation, I. R.; data curation, H. S.; writingoriginal draft preparation, K. B.; writing-review and editing, H. S.; visualization, K. B.; supervision, H. S.

\section{References}

Al Hadidi, F., \& Baghdadi, Y. (2019). Ontology for Enterprise Interactions: Extended and Virtual Enterprises. In ICT for a Better Life and a Better World (pp. 365-379). Springer, Cham. [Google Scholar] [CrossRef]

Alac, P. (2018). Application of Multi Criteria Decision Making Methods for the Evaluation of Logistics Processes in Particular Woodprocessing Enterprise. In Actual scientific research (pp. 47-54).

Aleksandrova, O. M. (2015). The current state and problems of the clothing market in Ukraine. Bulletin of the student scientific society «VATRA» of Vinnitsa Trade and Economic Institute. KNTEU, (24), 8-19.

Alzoubi, Y. I., Gill, A. Q., \& Moulton, B. (2018). A measurement model to analyze the effect of agile enterprise architecture on geographically distributed agile development. Journal of Software Engineering Research and Development, 6(1), 4. [Google Scholar] [CrossRef]

Asaul, A., Voynarenko, M., Dzhulii, L., Yemchuk, L., Skorobohata, L., \& Mykoliuk, O. (2019, June). The latest information systems in the enterprise management and trends in their development. In 2019 9th International Conference on Advanced Computer Information Technologies (ACIT) (pp. 409-412). [Google Scholar] [CrossRef]

Ashkezari, A. D., Hosseinzadeh, N., Chebli, A., \& Albadi, M. (2018). Development of an enterprise Geographic Information System (GIS) integrated with smart grid. Sustainable Energy, Grids and Networks, 14, 25-34. [Google Scholar] [CrossRef]

Bacho, R., Pukala, R., Hlibko, S., Vnukova, N., \& Pola, P. (2019). Information Management: the Key Driver of the Economic System's Development. Marketing and Management of Innovations, 3, 297-307. [Google Scholar] [CrossRef]

Badiru, A. B., Ibidapo-Obe, O., \& Ayeni, B. J. (2018). Manufacturing and Enterprise: An Integrated Systems Approach. CRC Press. [Google Scholar] [CrossRef]

Bilan, Y., Streimikiene, D., Vasylieva, T., Lyulyov, O., Pimonenko, T., \& Pavlyk, A. (2019). Linking between renewable energy, $\mathrm{CO} 2$ emissions, and economic growth: Challenges for candidates and potential candidates for the EU membership. Sustainability, 11(6), 1528. [Google Scholar] [CrossRef]

Boichenko, K. S., Tepliuk, M. A., Rekova, N. Y., Stashkevych, I. I., \& Morkunas, M. (2019). Management of fluctuation of financial and economic integrated development of innovative enterprise. Financial and credit activity: problems of theory and practice, 3(30), 62-69. [Google Scholar]

Boiko, V. S., Tarasova, K. I. (2019). Analysis of the development of light industry in Ukraine. Statistics - a tool for socio-economic research. Odesa, ONEU, pp. 52-60.

Bork, D., Gerber, A., Miron, E. T., van Deventer, P., Van der Merwe, A., Karagiannis, D.,... \& Sumereder, A. (2018, June). Requirements engineering for model-based enterprise architecture management with Arc.hiMate. In Workshop on Enterprise and Organizational Modeling and Simulation (pp. 16-30). Springer, Cham. [Google Scholar] [CrossRef]

Boudreau, J. W. (2016). IBM's Global Talent Management Strategy: The Vision of the Globally Integrated Enterprise. SAGE, pp. 1-2. [Google Scholar]

Chavarría-Barrientos, D., Batres, R., Wright, P. K., \& Molina, A. (2018). A methodology to create a sensing, smart and sustainable manufacturing enterprise. International Journal of Production Research, 56(1-2), 584-603. [Google Scholar] [CrossRef]

Chofreh, A. G., Goni, F. A., \& Klemes, J. J. (2018). Sustainable enterprise resource planning systems implementation: A framework development. Journal of cleaner production, 198, 1345-1354. [Google Scholar] [Google Scholar]

Deineko, L. V., Zymovets, V. V., Sheludko, N. M., \& Yanenkoval, H. (2018). Development of industry as a driver for growth and renewal of Ukraine's economy. NAS of Ukraine, State Institution «Institute of Economics and Forecasting». Kyiv, 51-59. 
I., Reshetnikova, H., Shvydanenko, K., Boichenko. Determinants to Provide the Efficiency of Integrated Development of the Light Industry Enterprises.

Downs, T. J. (2018). An Integrative Socio-Technical Enterprise Approach to Urban Design/Planning for Sustainable Development. Open Journal of Civil Engineering, 8(02), 183. [Google Scholar] [CrossRef]

Ershova, N., Yutkina, O., Pashkov, A., Ivanova, M., \& Chistyakova, A. (2018). Influence of human capital on the level of innovation activity of an enterprise. In MATEC Web of Conferences (Vol. 239, p. 04011). EDP Sciences [Google Scholar] [CrossRef

Handayani, S., \& Nirwan, S. (2019, October). Analysis and Design of Integrated Marketing Communication (Imc) for Small and Medium Enterprise (Sme) Logistics Service Provider (Lsp) from Web Based Application Perspective. In The 1 International Conference on Innovation of Small Medium-sized Enterprise (ICIS) 2019 (Vol. 1, No. 1, pp. 45-46).

Hryshchenko, I. M., Danylkovych, A. H., \& Mokrousova, O. R. (2015). Fur market in Ukraine and the world. Light industry, 4, 40-43.

Information and analytical agency APK-Inform. (2019). Anti-records in the flax market in Ukraine. Retrieved from https://www.apk-inform.com/ru/news/1502872

Jung, J. Y., Kim, H., \& Kang, S. H. (2006). Standards-based approaches to B2B workflow integration. Computers \& Industrial Engineering, 51(2), 321-334. [Google Scholar] [CrossRef]

Lyulyov, O., \& Shvindina, H. (2017). Stabilization Pentagon Model: application in the management at macro-and microlevels. Problems and Perspectives in Management, 15(3), 42. [Google Scholar]

Ma, C., \& Wang, J. (2016). Enterprise information management system integration based on internet of things technology. Management \& Engineering, (22), 12. [Google Scholar]

Mayer, N., Aubert, J., Grandry, E., Feltus, C., Goettelmann, E., \& Wieringa, R. (2019). An integrated conceptual model for information system security risk management supported by enterprise architecture management. Software \& Systems Modeling, 18(3), 2285-2312. [Google Scholar] [CrossRef]

Moisescu, M. A., \& Sacala, I. S. (2016). Towards the development of interoperable sensing systems for the future enterprise. Journal of Intelligent Manufacturing, 27(1), 33-54. [Google Scholar] [CrossRef]

Pietruszka-Ortyl, A. (2019). The Impact of Organizational Culture for Company's Innovation Strategy. Marketing and Management of Innovations, 3, 178-192. [Google Scholar] [CrossRef]

Petrenko, V., \& Melnykova, K. (2018). Formation of vertically integrated agrarian enterprises with foreign capital. Technology transfer: innovative solutions in Social Sciences and Humanities, 13-15. [Google Scholar] [CrossRef]

Prause, G., Hoffmann. T. (2020). Innovative Management of Common-Pool Resources by Smart Contracts. Marketing and Management of Innovations, 1, 265-275. [Google Scholar] [CrossRef]

State Statistics Service of Ukraine (2020). Commodity structure of foreign trade in 2019. Retrieved from http://www.ukrstat.gov.ua/operativ/operativ2019/zd/tszitt/tsztt u/tsztt1219 u.htm

Vasylieva, T., Lyeonov, S., Lyulyov, O., \& Kyrychenko, K. (2018). Macroeconomic stability and its impact on the economic growth of the country. Montenegrin Journal of Economics, 14(1), 159-170. [Google Scholar] [CrossRef]

Wu, C. (2019). Strategic Development Path and Innovation Path of Logistics Enterprise Based on Supply-side Reform. [Google Scholarl

Zhang, J., Xie, H., Li, H., Timothy, R., Pu, S., Deng, Q., \& Jin, W. (2018). Integrated framework of growth management for identification of service innovation levels and priorities. Sustainability, 10(9), 3319. [Google Scholar] [CrossRef]

Ірина Решетнікова, д.е.н., професор, ДВНЗ «КНЕУ імені В. Гетьмана», Україна

Генефа Швиданенко, к.е.н., професор, ДВНЗ «КНЕУ імені В. Гетьмана», Україна

Катерина Бойченко, к.е.н., доцент, ДВНЗ «КНЕУ імені В. Гетьмана», Україна

Детермінанти забезпечення ефективності інтегрованого розвитку підприємств легкої промисловості

Дана стаття узагальнює аргументи та контраргументи в межах наукового дискурсу з проблематики інтегрованості розвитку підприємств у сучасних ринкових умовах господарювання. Основною метою проведеного дослідження є формування методичного підходу до оцінювання і підвищення ефективності інтегрованого розвитку підприємств легкої промисловості України на засадах ідентисфікації ключових детермінант. Для забезпечення широкого і систематичного підходу в даному дослідженні було прийнято трьохетапну методичну основу: по-перше, проведено інтерпретацію і синтез якісних даних иляхом просіювання і сортування матеріалів з ключових питань $і$ тематики розвитку підприємств у контексті інтегрованості; по-друге, проаналізовано тенденції розвитку підприємств легко промисловості України з метою ідентиффікації ключових детермінант; по-третє, проведено оцінювання їх впливу на результативність інтегрованого розвитку підприємств. Методичним інструментарієм проведеного дослідження використано діалектичний та структурно-аналітичний, а також структурно-функціональний аналізи. Для визначення впливу ідентифікованих детермінант використано методи багатокритеріального аналізу, зокрема, розрахунок багатофакторної функиії корисності і нормалізація визначених факторів.B статті наведено результати емпіричного аналізу розвитку підприємств легкої промисловості за такими ключовими детермінантами, як забезпечення власною сировиною, наявність спеиіалізованого машинобудування, ремонтної бази, відповідного кваліфікованого персоналу, розвитку функціонуючих підприємств. Здійснено діагностику інтегрованого розвитку п'ятнадияти підприємств легкої промисловості за такими визначеними основними детермінантами, як фрінансове та ресурсне забезпечення, 
l., Reshetnikova, H., Shvydanenko, K., Boichenko. Determinants to Provide the Efficiency of Integrated Development of the Light Industry Enterprises.

інтелектуальний та інноваційний потенціал, економічна безпека, рівень ризиків, самоінтегрованість, синергетичний есект інтегрованих бізнес-прочесів. Для визначення впливу даних детермінант використано методи багатокритеріального аналізу, зокрема, багатофакторну функцію корисності та нормалізацію індикаторів за результатами діагностики. Визначено групу підприємств, для якої на сучасному етапі рівень розвитку в контексті його інтегрованості є нижчим, ніж оцінений за методами класичної діагностики результативності діяльності. Також виокремлено компанії, на яких процеси інтегрованості є ефективними і мають перспективу розвитку. Встановлено, що впровадження інтегрованого розвитку з урахуванням повного комплексу його детермінант сприятиме підвищенню корисності та результативності функціонування досліджуваних підприємств легкої промисловості. Результати проведеного дослідження можуть бути корисними для підвищення ефективності розвитку вітчизняних підприємств на засадах інтегрованості.

Ключові слова: ефективність, інтегрований розвиток, корисність, модель, фрактор.

Manuscript received: 23.04.2020

(C) The author(s) 2020. This article is published with open access at Sumy State University. 